$1-1-1966$

\title{
A comparison of three methods of feeding hay to wintering yearling cattle
}

\author{
G. C. Anderson \\ C. J. Cunningham \\ J O. Heisham
}

Follow this and additional works at: https://researchrepository.wvu.edu/ wv_agricultural_and_forestry_experiment_station_bulletins

\section{Digital Commons Citation}

Anderson, G. C.; Cunningham, C. J.; and Heisham, J O., "A comparison of three methods of feeding hay to wintering yearling cattle" (1966). West Virginia Agricultural and Forestry Experiment Station Bulletins. 534.

https://researchrepository.wvu.edu/wv_agricultural_and_forestry_experiment_station_bulletins/489 
West Virginia University Libraries

308021009521334 
Digitized by the Internet Archive in 2010 with funding from

Lyrasis Members and Sloan Foundation 


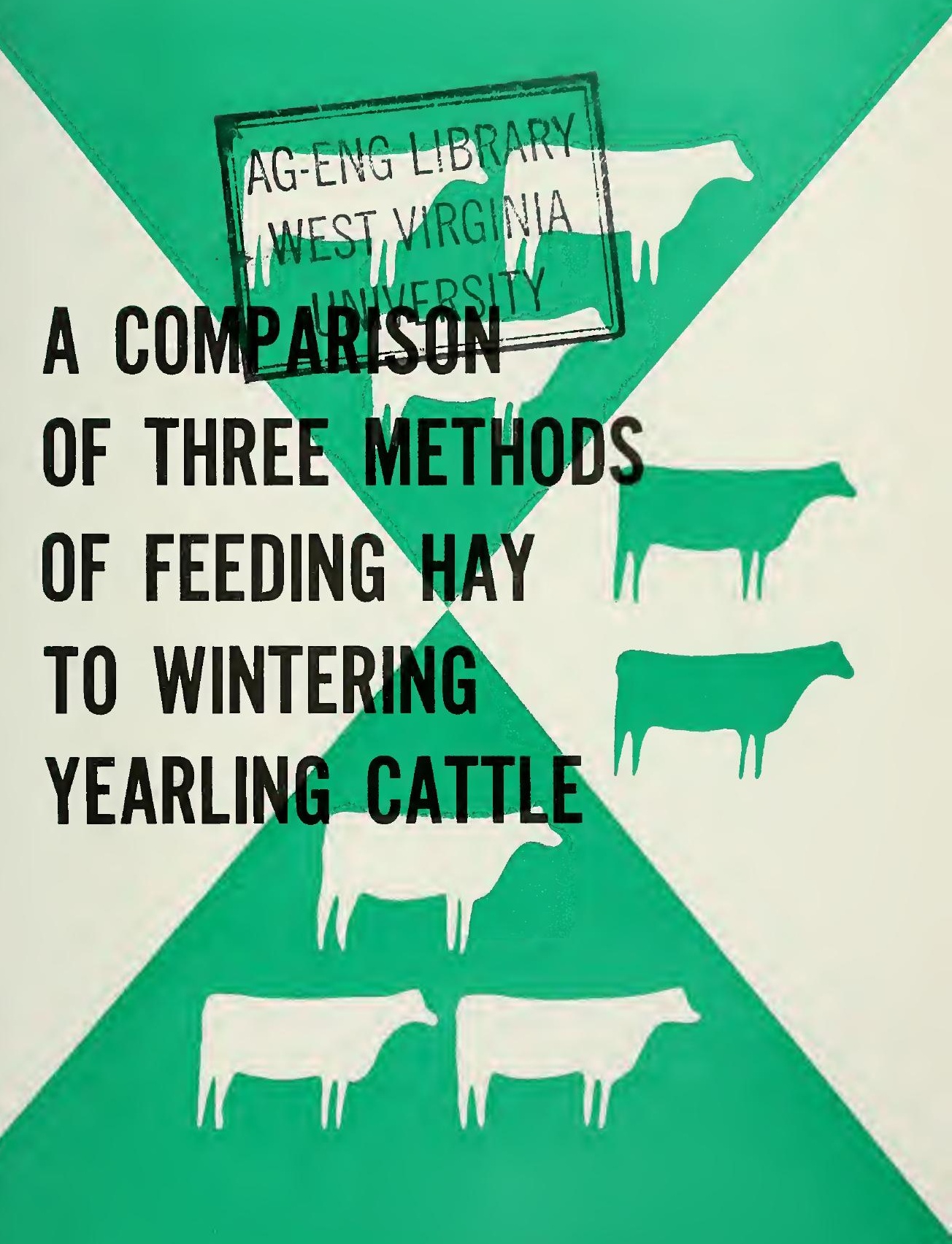

WEST VIRGINIA UNIVERSITY

AGRICULTURAL EXPERIMENT STATION 


\section{THE AUTHORS}

G. C. Anderson is Station Animal Husbandman; C. J. Cunningham is Station Animal Husbandman in charge of Reymann Memorial Farms Substation; and J. O. Heishman is Associate Station Animal Pathologist, Reymann Memorial Farms Substation.

West Virginia UNIVERSity Agricultural Experiment Station College of Agriculture and Forestry

A. H. Vanlandingham, Director Morgantown 


\section{A Comparison of \\ Three Methods of Feeding Hay To Wintering Yearling Cattle}

\section{G. C. ANDERSON, C. J. CUNNINGHAM, and J. O. HEISHMAN}

THE PURPOSE of these trials was to determine the comparative ad-

1 vantages of feeding baled hay in three different ways to cattle wintered in the open. One group of cattle was fed hay in a rack daily in an amount equivalent to 2.3 pounds per 100 pounds of body weight. The second group was fed an equivalent amount of hay but it was spread on the ground at each daily feeding. Hay for the third group of cattle was placed in a rack once each week in an amount which would permit the animals to have all they wanted to eat during the week.

These trials were conducted during three winter seasons beginning in 1960. The grade Hereford heifers and steers used were about 18 months of age at the beginning and about two years of age when a trial was completed. For each trial there were three uniform groups of heifers and three similar groups of steers. These groups were combined at random to form three mixed groups of steers and heifers to make up the three experimental groups.

The cattle were weighed on three consecutive days at the beginning and at the end of the trials. The beginning and ending weights are the averages of these weighings. These weights were obtained after feeding or when the cattle were full.

The cattle were wintered in the open. The three areas used were comparable in terms of topography and air drainage and were located on the lee side of a mountain. Prior to the ending of each trial, all areas were grazed heavily with cattle and sheep in order to remove any accumulated herbage which might have influenced performance.

The actual beginning and ending of a trial was largely dictated by weather conditions and their effect on grazing. In any case, the trials were started after the pastures could no longer provide an appreciable amount of feed. The trials were ended as soon as spring growth of grass came on. In this way the performance of the cattle was not disturbed by the amount of feed they could have harvested through grazing. Generally, the feeding period included December, January, and February. 
The average performance of the cattle during the three trials is presented in Table 1. The results of each trial are presented in Appendix Table A. The difference in performance between the daily- and weeklyfed groups is not unexpected and can be largely explained on the basis of the difference in the amount of feed available. The weekly-fed groups were offered an average of 2,170 lbs. of hay per head during the feeding periods, whereas the cattle fed hay daily in the rack and on the ground were offered 1,519 and 1,476 lbs., respectively. The difference amounts to about $600 \mathrm{lbs}$., or $6 \mathrm{lbs}$. of hay per head per day. Feeding this liberally permitted the weekly-fed cattle to sort through their hay and perhaps select a more nutritious ration. The amount of hay wasted by the weeklyfed groups suggested that they in fact did this.

Since the groups fed daily in a rack or on the ground received about the same amount of hay similar performance would be expected. This was not the case, however, for the rack-fed cattle maintained their weight (average gain of $3 \mathrm{lbs}$.), whereas cattle fed on the ground lost an average of $23 \mathrm{lbs}$. during a trial. Obvious feed wastage was surprisingly small and could not have been responsible for the inferior performance of the cattle fed on the ground. However, this method would result in loss of the finer, more leafy parts of the plant which are usually higher in feed value and would be saved by rack feeding. This suggests that rack feeding is to be preferred when the hay to be fed is fine and leafy.

The differences in weight shown in Table 1 could be influenced to some extent by fill despite precautions to the contrary. However, the weight records are supported by visual appraisal of the cattle. Although differences in weight and condition were evident, no apparent differences existed between the three groups in respect to thriftiness and general health. In usual experience such differences in weight are lost through compensatory gains during the subsequent grazing season. Reproduction

\section{TABLE 1}

\section{Summary of Wintering Performance (Average Wintering Period, 102 Days)}

\begin{tabular}{|c|c|c|c|c|c|}
\hline \multirow{2}{*}{$\begin{array}{c}\text { Method of } \\
\text { Feeding }\end{array}$} & \multirow{2}{*}{$\begin{array}{c}\text { Number } \\
\text { of } \\
\text { Cattle }\end{array}$} & \multicolumn{2}{|c|}{ Average Weight } & \multirow{2}{*}{$\begin{array}{l}\text { Weight } \\
\text { Gain or } \\
\text { Loss }\end{array}$} & \multirow{2}{*}{$\begin{array}{l}\text { Value of } \\
\text { Weight }^{*} \\
\text { Change }\end{array}$} \\
\hline & & Beginning & Ending & & \\
\hline Rack, daily & 39 & $\begin{array}{l}\text { lbs. } \\
647\end{array}$ & $\begin{array}{l}\text { lbs. } \\
650\end{array}$ & $\begin{array}{l}\text { lbs. } \\
+\quad 3\end{array}$ & $\begin{array}{c}\$ \\
+060\end{array}$ \\
\hline Ground, daily & 40 & 635 & 612 & $\begin{array}{l}+3 \\
-23\end{array}$ & $\begin{array}{l}+0.60 \\
-4.60\end{array}$ \\
\hline Rack, weekly & 40 & 645 & 670 & +25 & +5.00 \\
\hline
\end{tabular}

${ }^{\circ}$ Value of $\$ 20.00$ per hundredweight used. 
TABLE 2

\section{Summary of Feed, Labor, and Machinery Costs* (Average Wintering Period, 102 Days)}

\begin{tabular}{|c|c|c|c|c|c|c|c|}
\hline \multirow{3}{*}{$\begin{array}{l}\text { Method } \\
\text { of } \\
\text { Feeding }\end{array}$} & & & \multicolumn{2}{|c|}{ Labor } & \multirow{3}{*}{$\begin{array}{c}\text { Mach. } \\
\text { Use }\end{array}$} & \multirow{3}{*}{$\begin{array}{l}\text { Labor } \\
\text { and } \\
\text { Mach. } \\
\text { Costs } \dagger \dagger\end{array}$} & \multirow{3}{*}{$\begin{array}{c}\text { Total } \\
\text { Wintering } \\
\text { Cost }\end{array}$} \\
\hline & \multicolumn{2}{|c|}{ Hav $*$} & & Manure & & & \\
\hline & Amount & Cost & Feeding & Removal & & & \\
\hline & lbs. & $\$$ & hrs. & hrs. & hrs. & $\$$ & $\$$ \\
\hline Rack, daily & 1519 & 15.19 & 4.04 & .238 & .456 & 5.65 & 20.84 \\
\hline Ground, daily & 1476 & 14.76 & 4.04 & 000 & 000 & 4.04 & 18.80 \\
\hline Rack, weekly & 2170 & 21.70 & 1.09 & .69 & 1.34 & 5.80 & 27.50 \\
\hline
\end{tabular}

* All figures on a per head basis.

\$20.00 per ton.

$+\$ 1.00$ per hr.

$\uparrow+\$ 3.00$ per hr. (average cost for use of truck, tractor, manure loader and spreader).

was not influenced by treatment, as determined by performance of the heifers which were bred during the spring following each trial.

The amounts of feed, labor, and machinery used with each system of feeding are presented in Table 2 and Appendix Table B. In terms of the way the trials were conducted, the only real difference in the amount of hay fed would be between the weekly rack feeding and the other two methods. Daily feeding, either in a rack or on the ground, required approximately 60 per cent more time for feeding than did feeding once weekly. Although this method saved time, about 40 per cent more hay was used. Observations indicated that a good portion of this was pulled out of the rack and wasted.

The congregation of animals about the feeding racks led to an accumulation of manure. The removal of this manure and spreading it increased the cost of rack feeding. This disadvantage might be tempered by moving the rack before each feeding. It should be recognized, however, that the droppings on the wintering areas were not spread with a drag or harrow as would be done in keeping with good pasture management. Thus, this cost was not charged against the ground feeding method.

The amount of hay fed daily provided the cattle with about all they would eat. If the amount offered had been less than this, competition at the rack would have prevented the less aggressive animals from getting their fair share. On the other hand, too little rack feeding space would have had the same effect. With reasonable distribution of the hay on the ground, each animal has a good chance to get its share of feed.

It should be remembered that the wintering trials were conducted on a well-drained, protected slope. Under less favorable drainage conditions, feeding on the ground might be inadvisable. 


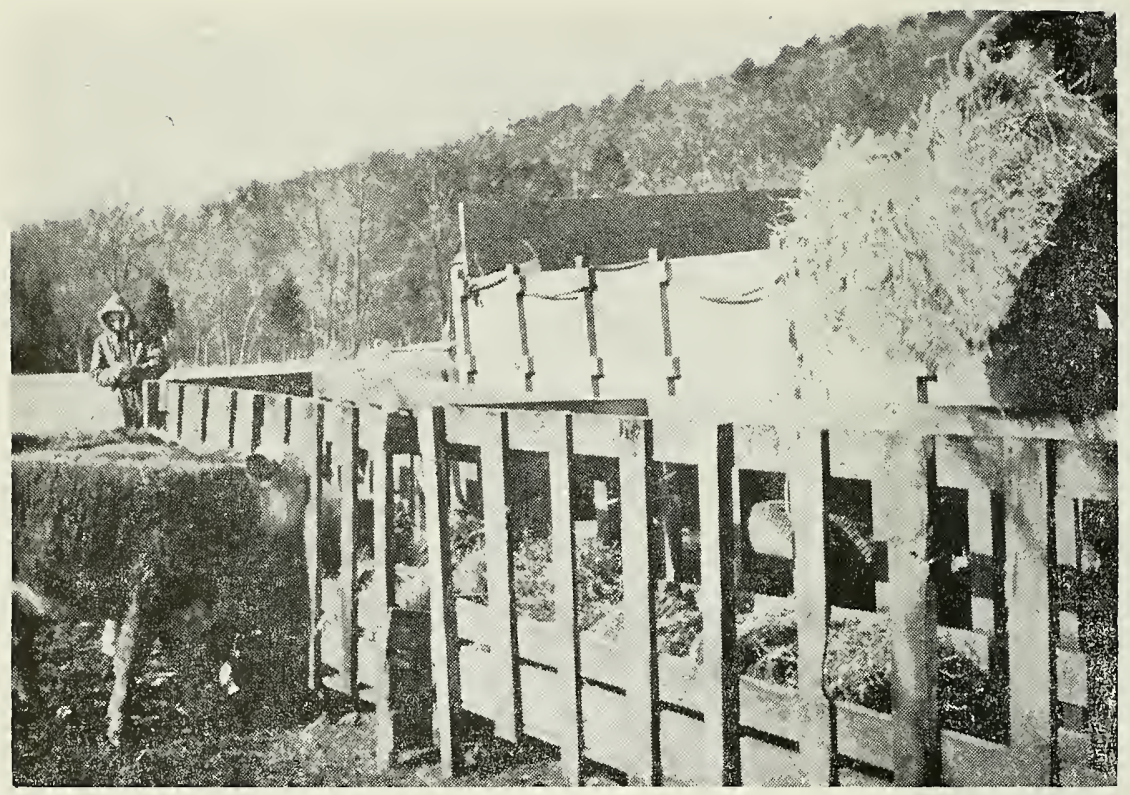

Figure 1. Hay was fed each day in racks such as these. Racks of similar design but greater capacity were used for weekly feeding. The wooded mountainside in the background provided shelter.

The results of these trials may be summarized as follows:

\section{Weekly Feeding in Rack}

1. Requires least time for feeding.

2. Results in greatest feed wastage.

3. Costs involved in removing manure from around rack may offset saving in feeding time.

4. Requires most feed.

5. Cattle gained an average of $25 \mathrm{lbs}$. during wintering period.

\section{Daily Feeding}

1. Requires more time for feeding.

2. Least feed wastage.

3. Major differences between rack and ground feeding were:

a. Cost of removing manure from around rack.

b. Cattle fed on ground lost weight, whereas those fed the same amount of hay from a rack maintained their weight, suggesting less feed wastage with this method. 


\section{APPENDIX TABLE A}

\section{Influence of Three Methods of Hay Feeding Upon the Winter Performance of Yearling Cattle}

\begin{tabular}{|c|c|c|c|c|}
\hline \multirow{2}{*}{$\begin{array}{l}\text { Feeding Method } \\
\text { and Lot Number }\end{array}$} & \multirow[b]{2}{*}{ No. of Head } & \multicolumn{2}{|c|}{ Average Weight } & \multirow{2}{*}{$\begin{array}{c}\text { Weight Cain } \\
\text { or Loss }\end{array}$} \\
\hline & & Initial & Ending & \\
\hline \multicolumn{5}{|c|}{ 1960-61-87 days } \\
\hline 1 & & & & \\
\hline \multirow[t]{3}{*}{ Rack, daily } & 4 steers & 697 & 667 & -30 \\
\hline & 9 heifers & 615 & 600 & -15 \\
\hline & 13 & 640 & 621 & -19 \\
\hline 2 & & & & \\
\hline \multirow[t]{3}{*}{ Ground, daily } & 5 steers & 652 & 611 & -41 \\
\hline & 9 heifers & 608 & 573 & -35 \\
\hline & 14 & 623 & 587 & -36 \\
\hline 3 & & & & \\
\hline \multirow{4}{*}{ Rack, weekly } & 5 steers & 665 & 685 & +20 \\
\hline & 9 heifers & 600 & 627 & +27 \\
\hline & 14 & 623 & 645 & +22 \\
\hline & \multicolumn{3}{|c|}{ 1961-62-107 days } & \\
\hline 1 & & & & \\
\hline \multirow[t]{3}{*}{ Rack, daily } & 4 steers & 613 & 631 & +18 \\
\hline & 8 heifers & 587 & 581 & +3 \\
\hline & 12 & 589 & 598 & +10 \\
\hline 2 & & & & \\
\hline \multirow[t]{3}{*}{ Ground, daily } & 4 steers & 637 & 625 & -12 \\
\hline & 9 heifers & 569 & 562 & -7 \\
\hline & 13 & 590 & 582 & -8 \\
\hline 3 & & & & \\
\hline \multirow[t]{4}{*}{ Rack, weekly } & 4 steers & 651 & 715 & +64 \\
\hline & 9 heifers & 586 & 634 & +48 \\
\hline & 13 & 606 & 659 & +53 \\
\hline & & -115 da & & \\
\hline 1 & & & & \\
\hline \multirow[t]{3}{*}{ Rack, daily } & 6 steers & 723 & 741 & +18 \\
\hline & 8 heifers & 682 & 702 & +20 \\
\hline & 14 & 703 & 722 & +19 \\
\hline 2 & & & & \\
\hline \multirow[t]{3}{*}{ Ground, daily } & 5 steers & 722 & 691 & -31 \\
\hline & 8 heifers & 666 & 649 & -17 \\
\hline & 13 & 694 & 670 & -24 \\
\hline 3 & & & & \\
\hline \multirow{3}{*}{ Rack, weekly } & 5 steers & 733 & 753 & +20 \\
\hline & 8 heifers & 685 & 668 & -17 \\
\hline & 13 & 709 & 710 & +1 \\
\hline
\end{tabular}




\section{APPENDIX TABLE B}

Hay Consumption, Labor and Machinery Costs Per Head for Wintering Yearling Beef Cattle by Three Methods

\begin{tabular}{|c|c|c|c|c|c|c|c|}
\hline \multirow[b]{2}{*}{$\begin{array}{l}\text { Feeding Method } \\
\text { and Lot Number }\end{array}$} & \multirow[b]{2}{*}{$\begin{array}{c}\text { Hay } \\
\text { Per Head }\end{array}$} & \multirow[b]{2}{*}{$\begin{array}{c}\text { Hay } \\
\text { Cost }^{*} \\
\text { Per Head }\end{array}$} & \multicolumn{3}{|c|}{ Labor $*$ Per Head } & \multirow{2}{*}{$\begin{array}{l}\text { Labor } \\
\text { and } \\
\text { Mach. } \dagger \\
\text { Costs }\end{array}$} & \multirow[b]{2}{*}{$\begin{array}{c}\text { Total } \\
\text { Wintering } \\
\text { Cost }\end{array}$} \\
\hline & & & $\begin{array}{c}\text { Feeding } \\
\text { (Hrs.) }\end{array}$ & $\begin{array}{l}\text { Manure } \\
\text { Man } \\
\text { (Hrs.) }\end{array}$ & $\begin{array}{c}\text { Removal } \\
\text { Mach. } \\
\text { (Hrs.) }\end{array}$ & & \\
\hline \multicolumn{8}{|c|}{$1960-61-87$ days } \\
\hline Rack, daily & 1300 & 13.00 & 3.85 & -0.285 & 0.4 & 5.42 & 18.42 \\
\hline $\begin{array}{c}\text { Ground, daily } \\
3\end{array}$ & 1200 & 12.00 & 3.57 & 000 & 000 & 3.57 & 15.57 \\
\hline Rack, weekly & 1957 & 19.57 & 1.07 & 0.50 & 0.71 & 3.70 & 23.27 \\
\hline \multicolumn{8}{|c|}{ 1961-62-107 days } \\
\hline Rack, daily & 1435 & 14.35 & 4.41 & 0.15 & 0.30 & 5.46 & 19.81 \\
\hline $\begin{array}{c}\text { Ground, daily } \\
3\end{array}$ & 1432 & 14.32 & 4.40 & 0.00 & 0.00 & 4.40 & 18.72 \\
\hline Rack, weekly & 2195 & 21.95 & .90 & 0.66 & 1.32 & 5.52 & 27.47 \\
\hline \multicolumn{8}{|c|}{ 1962-63-115 days } \\
\hline $\begin{array}{c}1 \\
\text { Rack, daily } \\
2\end{array}$ & 1823 & 18.23 & 3.85 & .28 & .64 & 6.05 & 24.28 \\
\hline $\begin{array}{c}\text { Ground, daily } \\
3\end{array}$ & 1796 & 17.96 & 4.15 & 0 & 0 & 4.15 & 22.11 \\
\hline Rack, weekly & 2359 & 23.59 & 1.31 & .92 & 2.00 & 8.23 & 32.82 \\
\hline
\end{tabular}

-\$20 per ton.

* $\$ 1.00$ per hr.

$\dagger \$ 3.00$ per hr. (average cost for use of truck, tractor, manure loader and spreader). 
